\title{
Oxygen fluxes involving the benthic micro- and macrophytic components in the Thau Lagoon under pre-anoxic conditions
}

\author{
Marie-Reine PLANTE-CUNY a , Raphaël PLANTE a , Nabila MAZOUNI ${ }^{\text {b }}$, Marie-France FONTAINE ${ }^{\text {a }}$ \\ Philippe SOUCHU ${ }^{\text {b }}$, Jean-Marc DESLOUS-PAOLI ', Christian GRENZ " \\ a Centre océanologique de Marseille (OSU-CNRS), université de la Méditerranée (Aix-Marseille II), UMR 6540 et 6535 , \\ station Marine d'Endoume, rue de la Batterie des Lions, 13007 Marseille, France \\ ${ }^{b}$ Laboratoire d'écologie conchylicole, Ifremer, BP 171, 1, rue Jean Vilar, 34200, Sète cedex, France
}

(Revised 2 October 1998, accepted 15 October 1998)

\begin{abstract}
Measurements of oxygen fluxes at the water-sediment interface (transparent and opaque enclosures) were made on bare sediments inhabited by microphytes on the one hand, and on sediments diversely colonized by macrophytes (macroalgae and seagrasses) on the other hand. Five stations, typical of different biotopes of a Mediterranean shallow lagoon were studied from May to July 1993 in order to observe an anoxic event which usually occurs at that time of the year. Average diurnal respiration of benthic communities ranged from $40 \mathrm{mg}$ (or $1.25 \mathrm{mmol}$ ) $\mathrm{O}_{2} \mathrm{~m}^{-2} \mathrm{~h}^{-1}$ in bare sediments ( $31 \%$ of the lagoon area) to $76 \mathrm{mg}$ (or $2.37 \mathrm{mmol}$ ) $\mathrm{O}_{2} \mathrm{~m}^{-2} \mathrm{~h}^{-1}$ in sediments with a medium coverage of macroalgae (37\% of the total area) and, finally, to $100 \mathrm{mg}$ (or $3.12 \mathrm{mmol}$ ) $\mathrm{O}_{2} \mathrm{~m}^{-2} \mathrm{~h}^{-1}$ in the denser macrophytic area ( $32 \%$ of the total area). The highest diurnal gross production was observed in the zone colonized by macroalgae and seagrasses, and especially in corridors between shellfish-cultivation tables $\left(300 \mathrm{mg} \mathrm{O}_{2} \mathrm{~m}^{-2} \mathrm{~h}^{-1}\right.$, or $9.37 \mathrm{mmol} \mathrm{O}_{2} \mathrm{~m}^{-2} \mathrm{~h}^{-1}$, equivalent to $113 \mathrm{mg} \mathrm{C} \mathrm{m}^{-2} \mathrm{~h}^{-1}$ ). Overall, during this period, net bottom oxygen production was close to nil in ca. $30 \%$, and positive in $70 \%$ of the lagoon area. The average net oxygen production for the whole lagoon in summer is thus in the order of $100 \mathrm{mg} \mathrm{O}_{2} \mathrm{~m}^{-2} \mathrm{~h}^{-1}$. In 1993, at the end of July, an anoxic event was avoided due to a period of strong wind. $\odot$ Elsevier, Paris
\end{abstract}

oxygen fluxes / micro-macrophytobenthos / Mediterranean coastal lagoon / Thau (France)

Résumé - Flux d'oxygène impliquant les compartiments micro et macrophytobenthiques dans l'étang de Thau en conditions pré-anoxiques. Les flux d'oxygène ont été mesurés à l'interface eau-sédiment (enceintes transparentes et opaques) d'une part, sur des sédiments apparemment nus (mais peuplés de microphytes), et d'autre part sur des sédiments plus ou moins couverts de macrophytes (macroalgues et phanérogames).

Cinq stations, caractéristiques des différents biotopes d'une lagune méditerranéenne peu profonde, ont été étudiées de mai à juillet 1993, dans le but de saisir un des épisodes d'anoxie habituels à cette époque. La respiration diurne d'oxygène des communautés benthiques (cloches noires) augmente en moyenne de $40 \mathrm{mg}$ (ou $1,25 \mathrm{mmol}_{2} \mathrm{O}_{2} \mathrm{~m}^{-2} \mathrm{~h}^{-1}$ sur les sédiments nus, représentant $31 \%$ de la surface totale de la lagune, à $76 \mathrm{mg}$ (ou $2,37 \mathrm{mmol}$ ) $\mathrm{O}_{2} \mathrm{~m}^{-2} \mathrm{~h}^{-1}$ vers les sédiments moyennement peuplés en macroalgues ( $37 \%$ de la surface totale) et jusqu'à $100 \mathrm{mg}$ (ou $3,12 \mathrm{mmol}$ ) $\mathrm{O}_{2} \mathrm{~m}^{-2} \mathrm{~h}^{-1}$ dans les zones densément peuplées de macrophytes ( $32 \%$ de la surface totale). La production brute diurne est maximale dans les zones à macrophytes avec phanérogames et en particulier dans les corridors entre les tables ostréicoles $\left(300 \mathrm{mg} \mathrm{O}_{2} \mathrm{~m}^{-2} \mathrm{~h}^{-1}\right.$ ou $9,37 \mathrm{mmol} \mathrm{O}_{2} \mathrm{~m}^{-2} \mathrm{~h}^{-1}$, ou encore équivalente à $113 \mathrm{mg} \mathrm{C} \mathrm{m}^{-2} \mathrm{~h}^{-1}$ ). À cette période pré-estivale et estivale de l'année, la production nette d'oxygène à la surface des sédiments est nulle pour environ 30 \% de la surface de la lagune et positive pour environ $70 \%$ de cette surface. En moyenne pour l'ensemble de la lagune, la production nette due aux végétaux benthiques est d'environ $100 \mathrm{mg} \mathrm{O}_{2} \mathrm{~m}^{-2} \mathrm{~h}^{-1}$. À la fin de juillet 1993, une crise anoxique a été évitée grâce à un fort coup de vent. (C) Elsevier, Paris

flux d'oxygène / micro-macrophytobenthos / lagune côtière méditerranéenne / Thau (France) 


\section{INTRODUCTION}

Within the balance of oxygen production and consumption at the sediment-water interface in shallow marine coastal lagoons, the phytobenthic compartment (including micro- and macrophytes) is principally an oxygen producer. However the interface between sediment and the water column is the site of numerous processes which bear heavily on the oxygen balance in nearshore waters. The benthic system consumes oxygen for various oxydative processes and the living communities (bacterial, vegetal and invertebrate communities) are oxygen consumers.

Measurements of interface fluxes must take into account the diversity of plant communities which live on such shallow sediments $[21,22]$. Apparently bare fine-grain sediments may be inhabited by populations of autotrophic benthic microphytes such as diatoms, dinoflagellates, microscopic chlorophytes and cyanobacteria. In other cases, macrophytes belonging to many families will also be dominant: phaeophytes, chlorophytes, rhodophytes and marine phanerogams.

The overall balance of oxygen production by benthic plants, which is normally positive, may be considerably altered by dystrophic crises which induce bacterial decomposition of macrophytes $[2,311$. These crises may occur during the summer in the Mediterranean coastal lagoons [19], with serious ecological and economical consequences [32]. The situation is even more complex in areas intensively used for aquiculture, as nutrient dynamics and oxygen consumption can be greatly modified due to excretion of various products $[6,16,18]$. Measurements of oxygen fluxes performed all along the seasonal cycle in enclosed water bodies, under different temperature and wind conditions, should allow for the time for oxic desequilibrium to begin to be observed.

As a continuation of previous surveys in an important Mediterranean lagoon which includes a shell cultivation site, the Thau Lagoon or étang de Thau $[1,10,20,23$, 32], we decided to follow the trends of oxygen flux fluctuations at the water-sediment interface, in different biotopes, in late spring and summer. During this period, primary production is high, but macrophyte decomposition tends to increase with higher water temperature. Anoxic events are known to occur.

Butlom areas with or without a dense macrophytic cover can be observed in the Thau Lagoon $[4,11]$; a situation which should allow estimation of the parts played by both benthic micro- and macrophytic communities in the oxygen balance, in the hope of finding some indicators of dystrophic crisis mechanisms.

The Thau Lagoon or étang de Thau was selected for the study of trends of oxygen flux fluctuations at the watersediment interface in spring and summer. During these seasons, primary production is high but macrophyte decomposition increases with water temperature and considerable background information is also available on the system which enhances our chances of understanding the processes leading to such anoxic events.

\section{MATERIAL AND METHODS}

\subsection{Study site: Thau Lagoon}

The Thau Lagoon $\left(43^{\circ} 24^{\prime} \mathrm{N}, 03^{\circ} 36^{\prime} \mathrm{E}\right)$, located on the French Mediterranean coast (SW of Montpellier), has an average depth of $4 \mathrm{~m}$ (locally up to $10 \mathrm{~m}$ ) and covers an area of about 7000 ha. There are two seawater inlets and several freshwater inputs from small streams. The ecological and hydrological conditions have been described by Amanieu et al. [1] and macrophyte populations have been characterised by Gerbal and Verlaque [12]. The main water body is the Grand Etang and a smaller diverticle in the northeastern part is the Etang des Eaux Blanches (figure 1). The former has been a site of extensive oyster production (Crassostrea gigas) for nearly thirty years; ca. $20 \%$ of the lagoon's surface is devoted to oyster farming and, to a lesser extent, to mussel farming in three dictinct zones (zones $\mathrm{A}$ and $\mathrm{B}$ are shown in figure l). The latter is separated from the former by a sill which partially isolates water masses: open sea water only penetrates into the Etang des Eaux Blanches; the Grand Etang is influenced by incoming seawater only when SE winds happen to blow $[3,29]$.

Five stations, described later, were located on different benthic biotopes of the lagoon: stations 1 and 2 in the central part of the Grand Etang outside the shellfish farm area, stations 3 and 5 respectively in the northwest and west parts in "corridors" inside the shellfish farming areas, and station 4 in the NE part of the lagoon (figure $l$, Etang des Eaux Blanches).

Measurements of bottom dissolved oxygen production and consumption were taken during four surveys in the period between 10 May and 30 July 1993. 


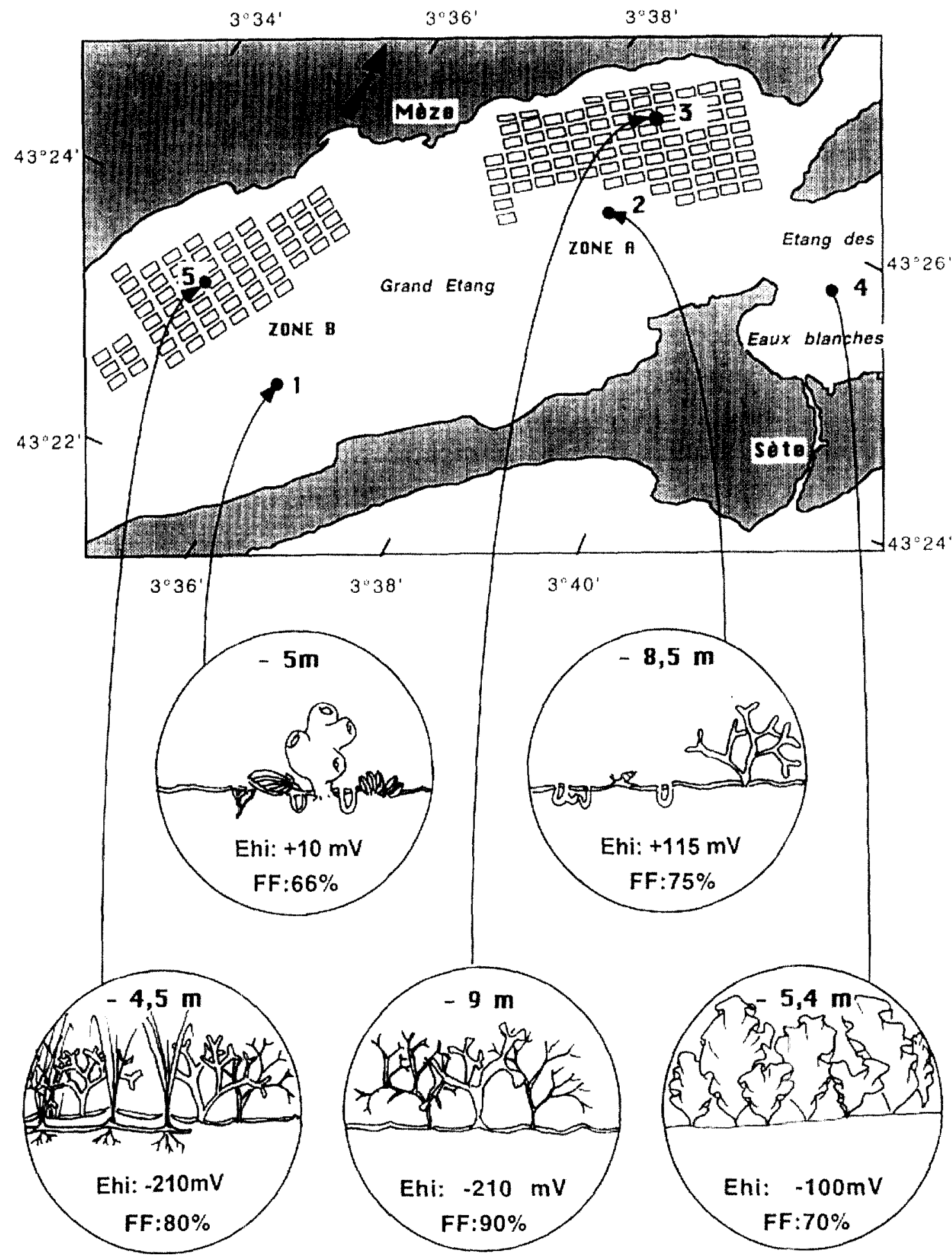

Figure 1. Study site: Thau Lagoon (NW Mediterrancan coast), Ehi: Water-sediment interface redox potential (mV), FF: Fine grain proportion of the superficial sediment. 


\subsection{Hydrological conditions during the surveys}

Surface water temperature oscillated between 18.5 and $20^{\circ} \mathrm{C}$ in May $(10-14$, table $I)$ and increased to $22.5-$ $24.3{ }^{\circ} \mathrm{C}$ in early July, decreasing to $21-22.9^{\circ} \mathrm{C}$ at the end of July, due to windy weather conditions on 26-27 July. In the same period. salinity increased steadily from ca. 34 in May to 37.6 at the end of July.

At the bottom level, dissolved oxygen concentrations (mid-morning measurements, table $n$ ) were higher than $6 \mathrm{mg} \mathrm{L^{-1 }}$ (max. $7.15 \mathrm{mg} \mathrm{L}^{-1}$ ) in May, whereas they decreased down to 6 or $5 \mathrm{mg} \mathrm{L}^{-1}$ in June and at the beginning of July (min. 4.95). Oxygen saturation values (expressed as percentages) were more than $80 \%$ ( $\max =96 \%$ in May), dropped down to $68 \%$ in May (station 5) and ca. $72 \%$ at the beginning of July (station 1). The general conditions of an oxic desequilibrium were setting in when a strong wind (force 4 to 5 ) occurred on the evening of the 26 July.

Table I. Hydrological conditions during the four surveys: temperature, salinity, dissolved $\mathrm{O}_{2}$ concentrations (mg $\mathrm{L}^{-1}$ and, between brackets, $\%$ of saturation) in surface and bottom waters, outside enclosures, at the start and the end of in situ experiments.

\begin{tabular}{|c|c|c|c|c|c|c|c|c|c|}
\hline & & \multicolumn{2}{|c|}{ 10-14 May } & \multicolumn{2}{|c|}{ 21-25 June } & \multicolumn{2}{|c|}{ 5.9 July } & \multicolumn{2}{|c|}{ 26-30 July } \\
\hline & & Start & End & Start & End & Start & End & Start & End \\
\hline \multirow[t]{2}{*}{ St $1(-5 \mathrm{~m})$} & & \multicolumn{2}{|c|}{12 May } & \multicolumn{2}{|c|}{24 June } & \multicolumn{2}{|c|}{5 July } & \multicolumn{2}{|c|}{$28 \mathrm{July}$} \\
\hline & $\mathrm{T}$ & $18.9^{\circ} \mathrm{C}$ & & $22.7^{\circ} \mathrm{C}$ & & $24.3^{\circ} \mathrm{C}$ & & $22.2^{\circ} \mathrm{C}$ & \\
\hline \multirow[t]{3}{*}{ Surface } & $S$ & 34.1 & & 35.5 & & 36.0 & & 37.4 & \\
\hline & $\mathrm{O}_{2}$ & & & & $7.00(100.4)$ & & & & \\
\hline & $\mathrm{T}$ & $18.3^{\circ} \mathrm{C}$ & $18.1^{\circ} \mathrm{C}$ & $22.7^{\circ} \mathrm{C}$ & $22.7^{\circ} \mathrm{C}$ & $23.5^{\circ} \mathrm{C}$ & $23.3^{\circ} \mathrm{C}$ & $22.2^{\circ} \mathrm{C}$ & $22.1^{\circ} \mathrm{C}$ \\
\hline \multirow[t]{2}{*}{ Bottom } & $\mathrm{S}$ & 34.4 & & 35.5 & & 36.1 & & 37.4 & \\
\hline & $\mathrm{O}_{2}$ & $6.19(80.59)$ & $6.02(78.24)$ & $5.96(85.55)$ & $6.76(97.36)$ & $4.95(71.70)$ & $5.23(75.76)$ & $5.72(80.88)$ & $7.21(100.5)$ \\
\hline \multirow{2}{*}{ St $2(-8.5 \mathrm{~m})$} & & \multicolumn{2}{|c|}{$10 \mathrm{May}$} & \multicolumn{2}{|c|}{23 June } & \multicolumn{2}{|c|}{9 July } & \multicolumn{2}{|c|}{30 July } \\
\hline & $\mathrm{T}$ & $19.0^{\circ} \mathrm{C}$ & & $22.9^{\circ} \mathrm{C}$ & $22.3^{\circ} \mathrm{C}$ & $22.9^{\circ} \mathrm{C}$ & & $22.9^{\circ} \mathrm{C}$ & \\
\hline \multirow[t]{3}{*}{ Surface } & $S$ & 34.2 & & 35.6 & & 36.4 & & 37.5 & \\
\hline & $\mathrm{O}_{2}$ & & & & $8.30(117)$ & & & $6.58(95.40)$ & \\
\hline & $\mathrm{T}$ & $16.7^{\circ} \mathrm{C}$ & $16.2^{\circ} \mathrm{C}$ & $19.7^{\circ} \mathrm{C}$ & $19.6^{\circ} \mathrm{C}$ & $22.0^{\circ} \mathrm{C}$ & $22.0^{\circ} \mathrm{C}$ & $21.2^{\circ} \mathrm{C}$ & $21.4^{\circ} \mathrm{C}$ \\
\hline \multirow[t]{2}{*}{ Bottom } & $\mathrm{S}$ & 35.1 & & 36.6 & & 36.6 & & 37.5 & \\
\hline & $\mathrm{O}_{2}$ & $6.82(84.70)$ & $6.59(82.34)$ & $5.13(69.15)$ & $6.42(87.32)$ & $5.42(77.15)$ & $5.52(78.11)$ & $5.70(80.47)$ & $6.29(90.07)$ \\
\hline \multirow[t]{2}{*}{ St $3(-9 \mathrm{~m})$} & & \multicolumn{2}{|c|}{$11 \mathrm{May}$} & \multicolumn{2}{|c|}{22 June } & \multicolumn{2}{|c|}{6 July } & \multicolumn{2}{|c|}{$27 \mathrm{July}$} \\
\hline & $\mathrm{T}$ & $18.5^{\circ} \mathrm{C}$ & & $23.5^{\circ} \mathrm{C}$ & & $23.3{ }^{\circ} \mathrm{C}$ & & $21.0^{\circ} \mathrm{C}$ & $21.0^{\circ} \mathrm{C}$ \\
\hline \multirow[t]{3}{*}{ Surface } & $\mathrm{S}$ & 34.0 & & 35.5 & & 36.0 & & 37.0 & \\
\hline & $\mathrm{O}_{2}$ & & & & & & & & \\
\hline & $\mathrm{T}$ & $17.0^{\circ} \mathrm{C}$ & $16.5^{\circ} \mathrm{C}$ & $19.6^{\circ} \mathrm{C}$ & $19.4^{\circ} \mathrm{C}$ & $21.7^{\circ} \mathrm{C}$ & $21.8^{\circ} \mathrm{C}$ & $21.0^{\circ} \mathrm{C}$ & $21.0^{\circ} \mathrm{C}$ \\
\hline \multirow[t]{2}{*}{ Bottom } & $\mathrm{S}$ & 35.5 & & 35.0 & & & & 37.5 & \\
\hline & $\mathrm{O}_{2}$ & $6.53(83.55)$ & $6.62(85.11)$ & $6.13(85.57)$ & $4.37(58.78)$ & $5.29(74.61)$ & $5.98(84.10)$ & $5.92(82.60)$ & $6.79(96.80)$ \\
\hline \multirow[t]{2}{*}{ St $4(-5.4 \mathrm{~m})$} & & $14 \mathrm{~N}$ & May & $25 \mathrm{Jl}$ & une & $8 \mathrm{Ju}$ & uly & $29 \mathrm{~J}$ & uly \\
\hline & $\mathrm{T}$ & $18.9^{\circ} \mathrm{C}$ & & $22.2^{\circ} \mathrm{C}$ & $22.7^{\circ} \mathrm{C}$ & $22.5^{\circ} \mathrm{C}$ & & $22.3^{\circ} \mathrm{C}$ & \\
\hline Surface & $\mathrm{S}$ & 34.5 & & 35.9 & & 36.5 & & 37.6 & \\
\hline & $\mathrm{O}_{2}$ & & & $8.06(113.8)$ & $6.95(98.67)$ & & & $7.10(99.00)$ & \\
\hline & $\mathrm{T}$ & $18.7^{\circ} \mathrm{C}$ & $18.8^{\circ} \mathrm{C}$ & $18.6^{\circ} \mathrm{C}$ & $19.1^{\circ} \mathrm{C}$ & $17.9^{\circ} \mathrm{C}$ & $18.2^{\circ} \mathrm{C}$ & $19.1^{\circ} \mathrm{C}$ & $18.7^{\circ} \mathrm{C}$ \\
\hline Bottom & $S$ & 34.5 & & 35.9 & & 37.2 & & 37.7 & \\
\hline & $\mathrm{O}_{2}$ & $7.15(95.91)$ & $10.19(138)$ & $6.05(80.01)$ & $8.53(113.8)$ & $6.03(79.70)$ & $7.15(95.30)$ & $4.83(64.54)$ & $4.53(60.24)$ \\
\hline St $5(-4.5 \mathrm{~m})$ & & $13 N$ & May & $21 \mathbf{J}$ & Iune & $7 \mathrm{Ju}$ & uly & $26 \mathrm{~J}$ & uly \\
\hline & $\mathrm{T}$ & $20.0^{\circ} \mathrm{C}$ & & $23.6^{\circ} \mathrm{C}$ & & $22.9^{\circ} \mathrm{C}$ & & $22.1^{\circ} \mathrm{C}$ & \\
\hline Surface & $\begin{array}{c}\mathrm{S} \\
\mathrm{O}_{2}\end{array}$ & 33.7 & & 35.6 & & 36.2 & & 37.1 & \\
\hline & $T^{2}$ & $18.8^{\circ} \mathrm{C}$ & $18.6^{\circ} \mathrm{C}$ & $22.5^{\circ} \mathrm{C}$ & $22.6^{\circ} \mathrm{C}$ & $22.7^{\circ} \mathrm{C}$ & $22.8^{\circ} \mathrm{C}$ & $21.8^{\circ} \mathrm{C}$ & $22.0^{\circ} \mathrm{C}$ \\
\hline Bottom & $\mathrm{S}$ & 34.3 & & 35.5 & & 36.2 & & 37.1 & \\
\hline & $\mathrm{O}_{2}$ & $6.06(80 ? 20)$ & $6.05(80.48)$ & $5.37(68)$ & $6.50(87.11)$ & $5.78(82.13)$ & $6.60(94.96)$ & $6.11(86.22)$ & $6.17(88.07)$ \\
\hline
\end{tabular}




\subsection{Geological and biogeochemical features of superficial sediments}

At all stations, percentage of the fine grain fraction in sediments $(\mathrm{FF}=\%$ of grain $<63 \mu \mathrm{m})$, redox potential (Ehi in $\mathrm{mV}$ ) at the water-sediment interface ([25] for methods), and chlorophyllous pigment concentrations in the top $10 \mathrm{~mm}$ layer of the sediment surface (spectrophotometry measurements before and after acidification, [24, 27]) were measured during each survey ( $\mathrm{Chl} a=$ chlorophyll $a$; Pheo = pheopigments $a$; Chl $a /$ Chl $a+$ Pheo; table II). Chlorophyll a mainly originates from benthic microphytes: live microphytic populations, mostly composed of diatoms and, to a lesser extent, of cyanobacteria, were observed under the microscope, ascertaining their autochthonous benthic origin $\left(10^{7}\right.$ to $10^{9}$ cells per $\mathrm{m}^{2}$, unpublished data). Sedimented planktonic algae were always in negligible proportions. Pheopigments $a$, were chlorophyll $a$ degradation products, mainly pheophorbid forms [27] of various origin (e.g. macrophyte debris, natural microphytic degradation and grazing processes).

Station $1(-5 \mathrm{~m}$; figure 1$)$ was representative of bare bottoms inhabited by benthic microphytes. During our surveys, the sediment was a muddy sand with an average FF of $66 \%$, the average Ehi was $+10 \mathrm{mV}$ and average concentrations of chlorophyllous pigments were $50 \mathrm{mg}$ Chla $\mathrm{m}^{-2}$ and $460 \mathrm{mg}$ Pheo $\mathrm{m}^{-2}$, in the top $1 \mathrm{~cm}$ layer of the sediment surface (table II).

Station 2 was deeper $(-8.5 \mathrm{~m})$, intermediate between bare sediments and bottoms sparsely covered with macroal- gae which were mainly Chaetomorpha and Gracilaria. Average grain-size was finer ( $\mathrm{FF}=75 \%)$, Ehi was higher $(+115 \mathrm{mV})$. Chlorophyllous pigments concentrations

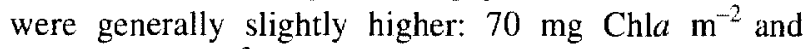
600 mg Pheo $\mathrm{Im}^{-2}$ on average.

Stations 3 and 5 were located at different depths (respectively -9 and $-4.5 \mathrm{~m}$ ) but both were inside the shellfish farm areas, in corridors between oyster-tables, densely populated with macroalgae (Chaetomorpha, Gigartina, Ceramium, Gracilaria, Polysiphonia, Cladophora, Enteromorpha), together with phanerogams at station 5 (Zostera). Because of biodeposition, sediments were obviously muddy (FF between 80 and $90 \%$ ) and the average Ehi were strongly negative in both cases (Ehi: $-210 \mathrm{mV}$ ). Pigment concentrations at the surface of sediments were high at both stations and fairly similar, pheopigment abundance being related to the high input of decaying macrophytic material (94 and $93 \mathrm{mg} \mathrm{Chla} \mathrm{m^{-2 }}$ respectively and 870 and $750 \mathrm{mg}$ Pheo $\mathrm{m}^{-2}$ respectively).

Station 4 ( $5.4 \mathrm{~m}$; Etang des Eaux Blanches) was covered with chlorophytes, (mainly Monostroma). The sediment was rather fine (FF: $70 \%$ ), also exhibiting a negative redox potential (Ehi: $-100 \mathrm{mV}$ ). Average pigment concentrations in the top $1 \mathrm{~cm}$ layer of the sediment surface

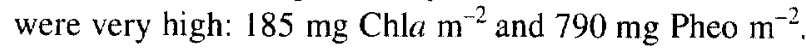
The high Chla concentration during the four surveys may be explained by numerous non-decaying chlorophyte debris, whereas the autochthonous microphytic population densities were not higher than in other stations.

Table II. Contents of chlorophyll $a$ and pheopigments $\left(\mathrm{mg} \mathrm{m}^{-2}\right)$ and ratio $\mathrm{Chl} a / \mathrm{Chl} a+$ Pheo in the top $1 \mathrm{~cm}$ of sediment at the five stations studied during four surveys. Average values for three core-samples \pm confidence intervals $(t, 5.5 / \sqrt{n})$.

\begin{tabular}{|c|c|c|c|c|c|c|}
\hline & & 10-14 May & 21-25 June & 5-9 July & 26-30 July & Mean \\
\hline St 1 & $\begin{array}{c}\text { Chl } a \\
\text { Pheo } \\
\text { Chl } a / \text { Chl } a+\text { Pheo }\end{array}$ & $\begin{aligned} & 42.37 \pm 13.86 \\
& 455.29 \pm 98.72 \\
& 0.09\end{aligned}$ & $\begin{array}{c}42.74 \pm 10.32 \\
407.58 \pm 109.00 \\
0.09\end{array}$ & $\begin{aligned} & 62.83 \pm 23.17 \\
& 438.94 \pm 81.12 \\
& 0.13\end{aligned}$ & $\begin{array}{c}57.62 \pm 20.17 \\
550.50 \pm 147.01 \\
0.09\end{array}$ & $\begin{array}{c}51.39 \pm 16.88 \\
463.08 \pm 108.96 \\
0.10\end{array}$ \\
\hline St 2 & $\begin{array}{c}\text { Chl } a \\
\text { Pheo } \\
\text { Chl } a / \text { Chl } a+\text { Pheo }\end{array}$ & $\begin{array}{c}83.36 \pm 29.37 \\
721.59 \pm 136.60 \\
0.10\end{array}$ & $\begin{array}{c}42.59 \pm 26.47 \\
423.64 \pm 131.69 \\
0.09\end{array}$ & $\begin{array}{c}83.66 \pm 74.73 \\
572.85 \pm 112.90 \\
0.19\end{array}$ & $\begin{array}{c}73.09 \pm 38.31 \\
661.46 \pm 120.40 \\
0.15\end{array}$ & $\begin{aligned} & 70.67 \pm 42.22 \\
& 594.88 \pm 125.39 \\
& 0.13\end{aligned}$ \\
\hline St 3 & $\begin{array}{c}\text { Chl } a \\
\text { Pheo } \\
\text { Chl } a / \text { Chl } a+\text { Pheo }\end{array}$ & $\begin{array}{c}78.34 \pm 40.36 \\
902.63 \pm 285.97 \\
0.08\end{array}$ & $\begin{array}{c}136.51 \pm 64.19 \\
828.43 \pm 257.50 \\
0.14\end{array}$ & $\begin{array}{c}101.47 \pm 39.69 \\
835.85 \pm 88.32 \\
0.12\end{array}$ & $\begin{array}{c}58.52 \pm 22.77 \\
900.25 \pm 157.48 \\
0.06\end{array}$ & $\begin{aligned} & 93.71 \pm 41.50 \\
& 866.79 \pm 197.32 \\
& 0.10\end{aligned}$ \\
\hline St 4 & $\begin{array}{c}\text { Chl } a \\
\text { Pheo } \\
\text { Chl } a / \text { Chl } a+\text { Pheo }\end{array}$ & $\begin{array}{c}209.54 \pm 104.33 \\
749.66 \pm 397.40 \\
0.22\end{array}$ & $\begin{array}{c}162.59 \pm 73.67 \\
655.37 \pm 256.96 \\
0.20\end{array}$ & $\begin{array}{c}221.62 \pm 98.32 \\
894.16 \pm 257.67 \\
0.20\end{array}$ & $\begin{array}{c}146.16 \pm 42.86 \\
869.44 \pm 239.29 \\
0.14\end{array}$ & $\begin{array}{c}184.97 \pm 79.79 \\
792.15 \pm 287.83 \\
0.19\end{array}$ \\
\hline St 5 & $\begin{array}{c}\text { Chl } a \\
\text { Pheo } \\
\text { Chl } a / \text { Chl } a+\text { Pheo }\end{array}$ & $\begin{aligned} & 96.47 \pm 31.17 \\
& 748.25 \pm 203.50 \\
& 0.11\end{aligned}$ & $\begin{array}{c}86.61 \pm 30.90 \\
670.64 \pm 122.91 \\
0.11\end{array}$ & $\begin{array}{c}138.85 \pm 43.18 \\
790.27 \pm 132.49 \\
0.15\end{array}$ & $\begin{array}{c}49.94 \pm 26.03 \\
793.91 \pm 211.96 \\
0.06\end{array}$ & $\begin{aligned} & 92.96 \pm 32.82 \\
& 750.77 \pm 167.71 \\
& 0.11\end{aligned}$ \\
\hline
\end{tabular}


Thus, these five stations showed physical and biological conditions which could be considered as representative of different biotopes of the lagoon diversely exposed to oxygen depletion.

\subsection{Methods for in situ measurement of benthic oxygen fluxes}

At the beginning of the measurement periods, enclosures made of polyacrylic hemispheres $(13.8 \mathrm{~L}$ covering $0.11 \mathrm{~m}^{2}$ ), were adapted onto embasements which had previously been driven gently into the bottom ensuring minimum disturbance [13]. During incubation time, which lasted up to six hours, continuous stirring of the water inside the bell-jar was ensured by a battery operated magnetic stirrer, to avoid concentration gradients.

Measurements of the dissolved oxygen concentrations were performed at regular intervals (ca. $1 \mathrm{~h}$ ), from $9 \mathrm{am}$ to $3 \mathrm{pm}$, universal time, by scuba divers operating two intercalibrated types of probes: an Orbisphere oxymeter (model 2609 equipped with a sensor, stirrer 2112, and a polarographic cell 2120, with automatic correction for salinity and temperature) on one set of three transparent and three opaque identical enclosures, and also a YSI polarographic oxymeter (model 58 with a 5739 probe) on another set of six transparent enclosures (see below).

Oxygen fluxes were calculated by pooling the data from replicates, calculating the slope of the regression of dissolved $\mathrm{O}_{2}$ concentrations against time, and then converting the results into $\mathrm{mg} \mathrm{O} \mathrm{O}_{2} \mathrm{~m}^{-2} \mathrm{~h}^{-1}[13,17]$. Dividing by a factor of 32 would give mmol $\mathrm{m}^{-2} \mathrm{~h}^{-1}$. The reason data were pooled for regression analysis rather than considered separately is that, in this case, we are using the regression slopes to obtain fluxes; the standard deviations on such regression slopes would be meaningless in further statistical analysis [13].

Three transparent and three opaque bell-jars were operated on each experiment and installed on the entire community (zoobenthos, micro- and macrophytes). The three transparent ones allowed a flux to be calculated, which is an estimate of the diurnal Net community Production of Oxygen (NOP), which was generally positive. The three dark ones of the same size, but completely opaque, installed in the same conditions, gave a flux which represented the oxygen Respiration of the whole Community (bacteria, plants and animals) plus the chemical demand of the sediment, under dark conditions (Community Respiration $=\mathrm{CR} ;[28])$.

The difference between these two values (NOP-CR), is an estimate of the Gross Oxygen Production by the plant community (GOP; $[9,21]$ ). As often encountered in the literature, this value can be converted into a rough estimate of the amount of absorbed $\mathrm{CO}_{2}$ or assimilated carbon by using a photosynthetic quotient of $\mathrm{I}$, a value which appears reliable enough in benthic environments $[7,8,15,26]$. Using a conversion factor of 0.375 between $\mathrm{O}_{2}$ and $\mathrm{C}$ gives an estimate of Carbon Assimilation (CA) in $\mathrm{mg} \mathrm{C} \mathrm{m} \mathrm{m}^{-2} \mathrm{~h}^{-1}$.

Six transparent bell-jars (15 L, $\left.0.114 \mathrm{~m}^{2}\right)$ were also installed on sediments previously hand-cleared of every macrophyte and, of course, partially cleared of microphytes. In this case flux measurements represent, as closely as possible, the sum of the Chemical and the Biological heterotrophic Oxygen Demand under light conditions, of sediments prepared in this way (COD+BOD).

\section{RESULTS}

Oxygen fluxes showed moderate variations during the study (from May to July). Therefore values for the four types of fluxes at the five stations may be compared on the basis of mean values for the whole survey (table $\mathrm{II}$, see confidence intervals for in situ measurements).

\subsection{Sediment demand of oxygen (COD+BOD)}

The total demand of oxygen (COD+BOD) of cleared sediments, was generally uniform at all five stations, except for a low average value observed at station 5 (* $^{*}-19 \mathrm{mg}$ $\mathrm{O}_{2} \mathrm{~m}^{-2} \mathrm{~h}^{-1}$, which includes an exceptional value of $+146 \mathrm{mg} \mathrm{O}_{2} \mathrm{~m}^{-2} \mathrm{~h}^{-1}$ on 7 July) whereas the three other observations at the same station gave an average value of $-75 \mathrm{mg} \mathrm{O}_{2} \mathrm{~m}^{-2} \mathrm{~h}^{-1}$ (lower line, $\mathrm{IC}= \pm 41$ ). The sediments from the two stations which are located in the corridors of shell-cultivation areas, and which were well covered with macrophytes before experiments (stations 3 and 5), appear slightly less oxygen-demanding ( -65 and $-75 \mathrm{mg}$ $\mathrm{O}_{2} \mathrm{~m}^{2} \mathrm{~h}^{-1}$ ) than those of the two other stations of the "Grand Etang" (St.1 and 2: -97 and $-104 \mathrm{mg} \mathrm{O}_{2} \mathrm{~m}^{-2} \mathrm{~h}^{-1}$ ). Station 4 (-105), previously well covered with macrophytes, is located in the Etang des Eaux Blanches a typical eutrophic area [30]. 
Table III. Average oxygen fluxes at the sediment-water interface at the five stations during the May-July 1993 period.

\begin{tabular}{|c|c|c|c|c|c|}
\hline Fluxes & $\begin{array}{c}\text { Station } 1 \\
-5 \mathrm{~m}\end{array}$ & $\begin{array}{c}\text { Station } 2 \\
-8.5 \mathrm{~m}\end{array}$ & $\begin{array}{c}\text { Station } 3 \\
-9 m\end{array}$ & $\begin{array}{c}\text { Station } 4 \\
-\mathbf{5 . 4 m}\end{array}$ & $\begin{array}{c}\text { Station } 5 \\
-4.5 \mathrm{~m}\end{array}$ \\
\hline $\mathrm{COD}+\mathrm{BOD}$ & $-97(12)$ & $-104(16)$ & $-65(24)$ & $-105(27)$ & $\begin{array}{c}-19(102)^{*} \\
-75(41)\end{array}$ \\
\hline NOP & $-12(29)$ & $+7(9)$ & $+115(73)$ & $+99(35)$ & $+199(9)$ \\
\hline $\mathrm{CR}$ & $-36(33)$ & $-51(12)$ & $-73(2)$ & $-79(37)$ & $-101(27)$ \\
\hline GOP & $24(13)$ & $58(3)$ & $188 \quad(71)$ & $178(50)$ & $300(37)$ \\
\hline $\mathrm{CA}$ & 9 & 22 & 71 & 67 & 113 \\
\hline
\end{tabular}

Values in $\mathrm{mg} \mathrm{O} \mathrm{O}_{2} \mathrm{~m}^{-2} \mathrm{~h}^{-1}$. Between brackets: interval of confidence $\pm t_{95} . \mathrm{s} / \sqrt{n}$.

COD + BOD: Chemical and Biological Oxygen Demand on scdiments hand-cleared of macrophytes and partially of microphytes

(six transparent bell jars)

* mean including an exceptional value

NOP: Net Oxygen Production (undisturbed community with benthic microphytes and eventually macrophytes; three transparent bell-jars)

CR: Community Respiration (plants, bacterial and animals respiration + COD; three opaque bell-jars)

GOP: Gross Oxygen Production (NOP-CR)

CA: Carbon assimilation $\left(\mathrm{mg} \mathrm{C} \mathrm{m}^{-2} \mathrm{~h}^{-1}\right)$

\subsection{Net production of oxygen}

For the net production of oxygen (NOP), all stations more or less covered by macrophytes exhibited positive oxygen fluxes. The highest average fluxes during the survey period were observed at stations 3,4 and 5 , with $+115,+99$ and $+199 \mathrm{mg} \mathrm{O}_{2} \mathrm{~m}^{-2} \mathrm{~h}^{-1}$ respectively. The shallowest station (station $5:-4.5 \mathrm{~m}$ ) extensively colonized by Zostera and macroalgae, was also the most oxygen-productive station. At station 2, a deep station with some macroalgae $(-8.5 \mathrm{~m})$, the average net production was low but positive $\left(+7 \mathrm{mg} \mathrm{O}_{2} \mathrm{~m}^{-2} \mathrm{~h}^{-1}\right)$. In contrast, at $-5 \mathrm{~m}$, on sediments only covered with microphytes (station 1), the average NOP was $-12 \mathrm{mg} \mathrm{O}_{2} \mathrm{~m}^{-2} \mathrm{~h}^{-1}$. indicating that oxygen production of the microphytic community was not compensating for the respiration of the heterotrophic organisms.

\subsection{Community respiration and gross oxygen production}

Community respiration was lowest at station 1 , the only microphyte-populated station ( $\left.\mathrm{CR}=-36 \mathrm{mg} \mathrm{O}, \mathrm{m}^{-2} \mathrm{~h}^{-1}\right)$. Station 2 exhibited an intermediate respiration value $\left(-51 \mathrm{mg} \mathrm{O}_{2} \mathrm{~m}^{-2} \mathrm{~h}^{-1}\right)$. The highest consumption rates of oxygen $\left(\mathrm{CR}=-73,-79\right.$ and $\left.-101 \mathrm{mg} \mathrm{O}_{2} \mathrm{~m}^{-2} \mathrm{~h}^{-1}\right)$ were observed where macrophytes were dense.

In approximate concordance with the above community respiration values, gross production results increased from station 1 ( $24 \mathrm{mg} \mathrm{O}_{2}$ or $9 \mathrm{mg} \mathrm{C} \mathrm{m}^{-2} \mathrm{~h}^{-1}$ ) to station 5 (300 $\mathrm{mg} \mathrm{O}_{2}$ or $113 \mathrm{mg} \mathrm{C} \mathrm{m}^{-2} \mathrm{~h}^{-1}$ ).

\subsection{Temporal changes}

Temporal changes in fluxes may be analysed at station 4 (Etang des Eaux Blanches, figure I), in which a dense, homogeneous and permanent cover of chlorophytes (Monostroma) was observed. As shown in figure 2 , chemical and biological oxygen demand under light conditions, on sediments cleared of algae (COD+BOD) were particularly high in May and June (ca. $-120 \mathrm{mg} \mathrm{O}_{2}$ $\mathrm{m}^{-2} \mathrm{~h}^{-1}$ ) and tended to decrease in July. At all other stations temporal changes of this oxygen demand were also moderate during the same period with the exception of station 5 , as already mentioned. The NOP showed an increase between June and July at station 4 (from +73 to $+140 \mathrm{mg} \mathrm{O}_{2} \mathrm{~m}^{-2} \mathrm{~h}^{-1}$ ). This was the case only for stations with macrophytes (stations 3 and 5 ), probably due to better conditions for the macrophyte photosynthesis. In July, values of NOP were stable at all stations. Overall at station 4 , the respiration of the community in the dark (CR) oscillated around $-79 \mathrm{mg} \mathrm{O} \mathrm{O}_{2}^{-2} \mathrm{~h}^{-1}( \pm 37$ ) (table III) ranging between $-40 \mathrm{mg} \mathrm{O}_{2} \mathrm{~m}^{-2} \mathrm{~h}^{-1}$ in mid May and ca. $-120 \mathrm{mg} \mathrm{O}_{2} \mathrm{~m}^{-2} \mathrm{~h}^{-1}$ at the end of June. The temporal changes of gross oxygen production (GOP) are linked to the net production values. The GOP tends to increase between May and July except for stations principally populated by microphytes (stations 1 and 2).

\section{DISCUSSION}

When trying to separate the part played by the sediment alone in the oxic interface balance, sediments deliberately "cleared" (i.e. with bacteria, animals, and residual 


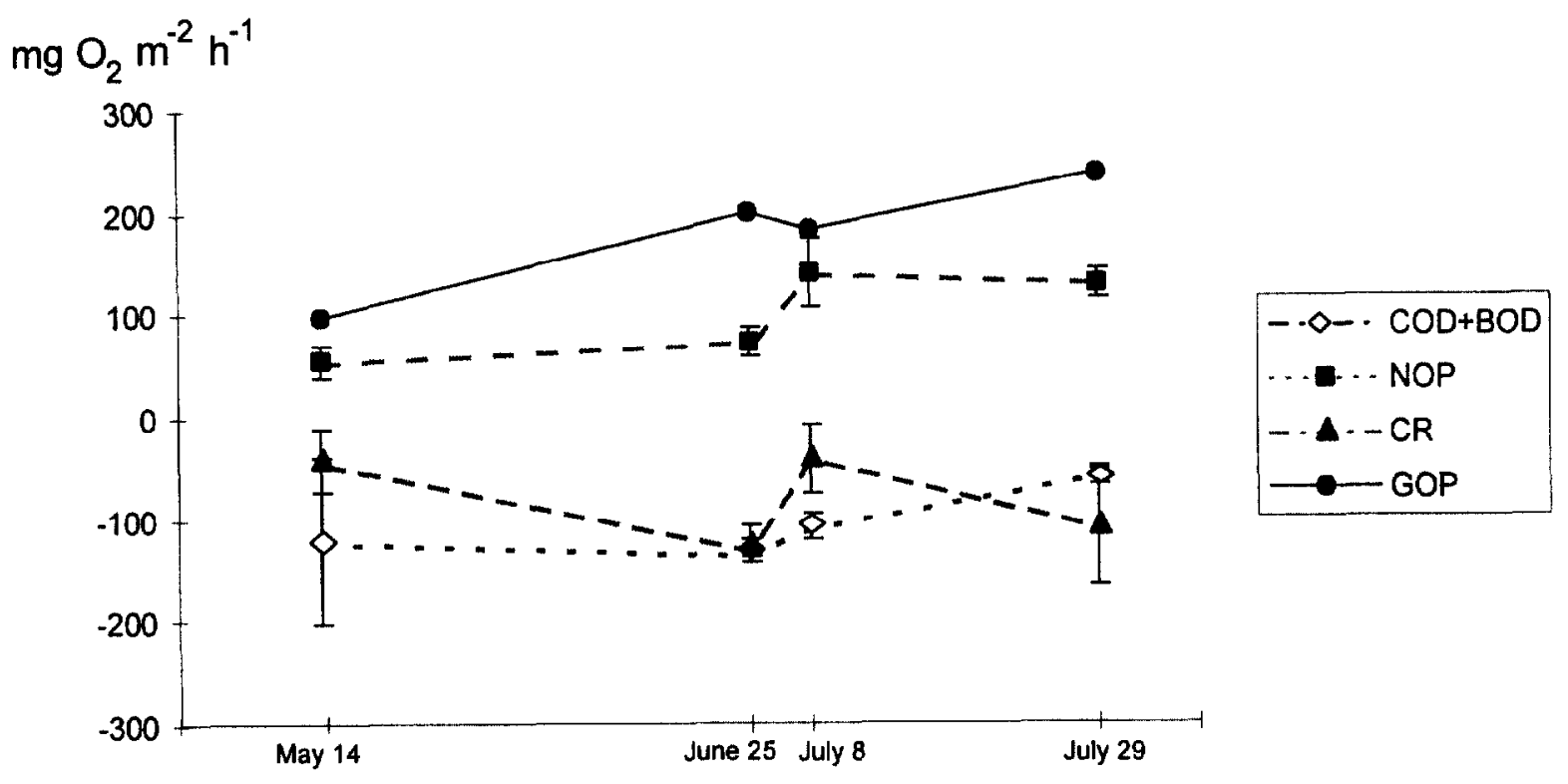

Figure 2. Changes in oxygen benthic fluxes at a station densely covered with macrophytes between May and July (station 4; Etang des Eaux Blanches). Vertical bars: confidence intervals $\left( \pm t_{95} . s / \sqrt{n}\right)$.

microphytes, but without the macrobenthic plant community), must be considered in order to estimate the sediment demand of oxygen (table III: COD+BOD). This then has to be compared to the respiration of the community with complete vegetation (CR). Overall fluctuations of the sediment oxygen demand among stations with different sediment types were small (see IC in table III). Oxygen demand was of the order of $100 \mathrm{mg} \mathrm{O}_{2} \mathrm{~m}^{-2} \mathrm{~h}^{-1}$ with the exception of two stations ( 3 and 5) located in the shellfish farm corridors, where the demand was surprisingly less ( -65 and $-75 \mathrm{mg} \mathrm{O}_{2} \mathrm{~m}^{-2} \mathrm{~h}^{-1}$ ). The bottom currents in these corridors reach values of $20 \mathrm{~cm} \mathrm{~s}^{-1}$ and probably improve the oxygenation of superficial sediments (C. Grenz, unpublished). Our results on cell microphytic counts indicate that there is less microphytobenthos under the dense cover of chlorophytes in the eutrophicated Etang des Eaux Blanches, which explains the relatively high value of the total demand there, in spite of paradoxically high values of chlorophyll $a$ content in this station. These high values (table II) are explained by the minute debris of chlorophytes, intermingled with sediment and produced by the browsing behaviour of dense Hydrobia populations.

The community respiration (opaque bells-jars: $\mathrm{CR}$ ) represents the "total demand" of the sediment, together with the demand of macrophytes and other enclosed organisms under non-photosynthetic conditions. The values of
CR together with sediment demand (COD+BOD) indicate that macrophytic impact is measurable: $C R$ varied between -51 and $-101 \mathrm{mg} \mathrm{O}_{2} \mathrm{~m}^{-2} \mathrm{~h}^{-1}$ according to the abundance of macrophytes at stations $2,3,4$ and 5 . Community respiration values were apparently more related to the epibiontic communities on macrophytes (bacteria and epifauna) than to the macrophytes themselves. This is especially obvious at station 5 , where $C R$ was higher than $\mathrm{COD+BOD}$ (cleared sediment, in which endofauna is still present). At stations where macrophytes were not present (station 1) or scarce (station 2), transparent enclosures (NOP) and dark ones (CR) were deliberately placed over sediments without aggregates of benthic animals to avoid exageration or heterogeneous estimates of oxygen consumption. At other stations, such aggregates could not be observed: this difference in visibility of organisms may perhaps explain why $\mathrm{CR}$ was lower than COD+BOD at stations 1 and 2 .

Net fluxes were positive and higher at stations with macrophytes. They were also higher at the two stations with macrophytes in the shellfish-farming areas (stations 3 and 5) than in the part with dense Monostroma cover (station 4). The highest net primary production estimate (+199 $\mathrm{mg} \mathrm{O}_{2} \mathrm{~m}^{-2} \mathrm{~h}^{-1}$ ) was obtained for an assemblage of macroalgae and seagrass (station 5). At this location and during our surveys, the plant community was healthy, not submitted to bacterial degradation which occurs under 
the confined and hyperthermal conditions liable to induce anoxic events (malaigue).

The plant communities of the Thau Lagoon were mapped in detail by Gerbal [11] and Gerbal and Verlaque [12], and we therefore located our stations in the different zones identified by these colleagues (table IV). Stations 1 and 2 are located in -and quite representative of - the "central part" (secteur central, ca. $31 \%$ of the total area). which the authors describe as nearly devoid of vegetation (plant biomass $=0$ to $25 \mathrm{~g} \mathrm{DW} \mathrm{m}^{-2}$ ).

Using our estimates for the spring and summer period, i.e. a rough hourly diurnal respiration of $40 \mathrm{mg}$ $\mathrm{O}_{2} \mathrm{~m}^{-2} \mathrm{~h}^{-1}(-36,-51)$ and a rough hourly diurnal gross production of $40 \mathrm{mg} \mathrm{O} \mathrm{m}^{-2} \mathrm{~h}^{-1}(24,58)$, we obtain no diurnal net production. Should our budget include the night time values, then an overall deficit of benthic oxygen in this "central part" during the study period would be observed.

Another major zone determined by Gerbal and Verlaque is the "east part" (31\% of the total area), which includes our stations 3 and 4 . For discussion purposes we will include in this part another fraction of the lagoon with roughly the same features (the "south-east part": $6 \%$ ). Thus, in $37 \%$ of the surface of the lagoon, plant biomass ranges from 25 to $225 \mathrm{~g} \mathrm{DW} \mathrm{m}^{-2}$. The average values of fluxes over this type of bottom were $76 \mathrm{mg} \mathrm{O}_{2} \mathrm{~m}^{-2} \mathrm{~h}^{-1}$ for the respiration and $183 \mathrm{mg} \mathrm{O}_{2} \mathrm{~m}^{-2} \mathrm{~h}^{-1}$ for the gross production, thus giving a daytime positive balance of $107 \mathrm{mg}$ $\mathrm{O}_{2} \mathrm{~m}^{-2} \mathrm{~h}^{-1}$. Considering that nocturnal respiration is not higher than diurnal, we may expect a positive circadian balance in such zones.

Station 5 can be considered representative of Gerbal and Verlaque's "west part" [12]. This zone, which covers $32 \%$ of the total lagunal surface, has a plant cover ranging from 225 to $700 \mathrm{~g} \mathrm{DW} \mathrm{m}^{-2}$. Calculation of average values of respiration and gross production lead to a diurnal hourly net production of $200 \mathrm{mg} \mathrm{O}_{2} \mathrm{~m}^{-2} \mathrm{~h}^{-1}$. Thus, in this zone the circadian $\mathrm{O}_{2}$ balance, in summertime, is strongly positive. The zones with macrophytes, which represent about $70 \%$ of the total bottom area of the lagoon thus contribute considerably to the input of oxygen in this ecosystem.

About $20 \%$ of the total surface of the lagoon is occupied by oyster cultivation structures. The sediment underneath oyster ropes is a fluid mud, generally richly colonized by benthic microphytes. In 1991-1992, we carried out seasonal measurements of the same parameters under the ropes, using the same methods and enclosures [5]. Springtime values of net production were slightly negative, whereas summer ones were positive $\left(+25 \mathrm{mg} \mathrm{O}_{2} \mathrm{~m}^{-2}\right.$ $\left.\mathbf{h}^{-1}\right)$. The respiration was also maximum during summer ( $-74 \mathrm{mg} \mathrm{O}_{2} \mathrm{~m}^{2} \mathrm{~h}^{1}$ ), but it was compensated for by the oxygen production of an abundant microphytobenthos (with a consequent gross production of about $100 \mathrm{mg}$ $\mathrm{O}_{2} \mathrm{~m}^{-2} \mathrm{~h}^{-1}$ ). Therefore, our measurements confirm that biodeposition areas below the oyster ropes in Thau Lagoon do not play a negative part in the oxygen balance, as already observed by Mazouni et al. [18] and Grenz et al. [14] during experimental studies on mud-removal

Table IV. General results on daily predictable benthic oxygen fluxes in summer, in the three main parts of the Thau Lagoon, according to the macrophytic biomasses $\left(\mathrm{g} \mathrm{DW} \mathrm{m}^{-2}\right.$ ). Data on the surfaces and biomasses from Gerbal and Verlaque [12].

\begin{tabular}{|c|c|c|c|c|}
\hline & $\begin{array}{c}\text { Diurnal Oxygen } \\
\text { Respiration } \\
\left(\mathrm{mgO}_{2} \mathbf{m}^{-2} \mathbf{h}^{-1}\right)\end{array}$ & $\begin{array}{l}\text { Gross Oxygen Production } \\
\qquad\left(\mathrm{mgO}_{2} \mathrm{~m}^{-2} \mathrm{~h}^{-1}\right)\end{array}$ & $\begin{array}{c}\text { Diurnal Net Oxygen } \\
\text { Production } \\
\left(\mathrm{mgO}_{2} \mathbf{m}^{-2} \mathbf{h}^{-1}\right) \\
\end{array}$ & $\begin{array}{l}\text { Circadian Oxygen } \\
\text { Balance in summer }\end{array}$ \\
\hline $\begin{array}{l}\text { Central part }(31 \%) \\
0-25 \mathrm{~g} \mathrm{DW} \mathrm{m^{-2 }} \\
\text { (Stations } 1 \text { and } 2)\end{array}$ & 40 & 40 & 0 & $<0$ \\
\hline $\begin{array}{l}\text { East and southeast part } \\
(37 \%) \\
25-225 \mathrm{~g} \mathrm{DW} \mathrm{m}^{-2} \\
\text { (Stations } 3 \text { and } 4 \text { ) }\end{array}$ & 76 & 183 & 107 & $>0$ \\
\hline $\begin{array}{l}\text { West and southwest par } \\
(32 \%) \\
225-700 \mathrm{~g} \mathrm{DW} \mathrm{m} \mathrm{m}^{-2} \\
\text { (Station 5) }\end{array}$ & 100 & 300 & 200 & $\gg 0$ \\
\hline $\begin{array}{l}\text { Average value for the } \\
\text { whole lagoon }\end{array}$ & 72.5 & 172 & 103.5 & $>0$ \\
\hline
\end{tabular}


effects in the same area. Furthermore we observed that the corridors between oyster-tables were densely populated with highly productive macrophytes.

As table III shows, a rough estimate of the oxygen balance at the surface of sediment as a whole gives positive values between May and July. To better understand the processes at the beginning of a dystrophic crisis, we need to examine $\mathrm{O}_{2}$ benthic balances during other periods of the year.

In 1991-1992, two stations of the seasonally study already mentioned [5] were located in shellfish farm area $\mathrm{B}$ of the lagoon (figure 1 ). One of those stations was located in a bare sediment zone, only populated with microphytes, at a depth of $5 \mathrm{~m}$, off the oyster structures. It can therefore be compared with our station 1. Barranguet et al. [5] observed that respiration was more intense in spring $\left(-38 \mathrm{mg} \mathrm{O}_{2} \mathrm{~m}^{-2} \mathrm{~h}^{-1}\right)$ and in summer $\left(-40 \mathrm{mg} \mathrm{O}_{2}\right.$ $\left.\mathrm{m}^{-2} \mathrm{~h}^{-1}\right)$, values quite comparable to those obtained in this study ( $-36 \mathrm{mg} \mathrm{O} \mathrm{O}_{2}^{-2} \mathrm{~h}^{-1}$ in 1993). Respiration was much lower during winter $\left(-12 \mathrm{mg} \mathrm{O} \mathrm{m}^{-2} \mathbf{h}^{-1}\right)$, which resulted in a positive net production $\left(+5 \mathrm{mg} \mathrm{O}_{2} \mathrm{~m}^{-2} \mathrm{~h}^{-1}\right)$. Afterwards, the production was negative in spring (-35 $\left.\mathrm{mg} \mathrm{O}_{2} \mathrm{~m}^{-2} \mathrm{~h}^{-1}\right)$ and slightly negative in summer $\left(-5 \mathrm{mg} \mathrm{O} \mathrm{m}^{-2} \mathrm{~h}^{-1}\right)$.

In 1991-1992, one of the four stations (station MC in [4]), densely populated with macrophytes, was located at a depth and location corresponding approximately to station 5. Diurnal hourly net fluxes were always positive except in summer where the respiration was remarkably high in early July. The respiration value on this occasion $\left(-115 \mathrm{mg} \mathrm{O} \mathrm{O}_{2} \mathrm{~m}^{-2} \mathrm{~h}^{-1}\right)$ was higher than at the three other stations ( -74 under the ropes, -40 and $-92 \mathrm{mg} \mathrm{O}_{2} \mathrm{~m}^{-2} \mathrm{~h}^{-1}$ outside) and much higher than our results in summer 1993. During summer 1992 [18] an anoxic event occurred (malaigue), which was probably predictable from the largely deficient $\mathrm{O}_{2}$ balance observed earlier at the water-sediment interface. This summer disequilibrium, which was highly destructive for the living community, including oysters, led us to plan the 1993 survey. However, temperature and hydrodynamic conditions were quite different from the previous year, with a cooling down of the water at the end of July $\left(23-24{ }^{\circ} \mathrm{C}\right.$ to $21-$ $22{ }^{\circ} \mathrm{C}$ ) due to a short period of strong wind. At the end of our survey, the oxygen balance was clearly positive, especially at stations with macrophytes, and no major anoxic event occurred during that summer (1993).

Our results suggest that it is unlikely that the bottom of the central zone $(31 \%)$, with an $\mathrm{O}_{2}$ balance close to nil in summer and positive in winter. would play a significant part in triggering bottom anoxia. But the rest of the lagoon, which is colonized by macrophytes exhibits high respiration rates and, under given climatic conditions (calm weather and high temperatures), this can enhance anoxic events.

\section{Acknowledgements}

This research was supported by the National French Programme PNOC (Programme national d'océanologie côtière, Oxythau) and by the Centre d'Océanologie de Marseilles (OSU-CNRS/ Université de la Méditerranée, URA 41). The authors would like to thank Pr E. Bourget, for his constructive comments and two anonymous reviewers for critical comments. Diving assistance was ensured by $C$. Jalong and technical assistance by E. Alivon.

\section{REFERENCES}

[1] Amanieu M., Legendre P., Trousselicr M., Frisoni G.F., Le programme Ecothau: théorie écologique et base de la modéljsation, Oceanol. Acta 12 (3) (1989) 189-199.

12] Andersen F.O., Hargrave B.T., Effects of Spartina detritus enrichment on aerobic/anaerobic benthic metabolism in an intertidal sediment, Mar. Ecol. Prog. Ser. 16 (1984) 161-171.

[3] Audouin J., Hydrologie de l'étang de Thau, Rev. Trav. Inst., Pêches marit. 26 (1) (1962) 5-104.

[4] Barranguet C., Alliot E., Variations spatio-temporelles des flux benthiques (oxygène et ammonium) et de la biomasse microphytobenthique darıs la zone conchylicole de l'étang de Thau (France), J. Rech. Océanogr: 20 (1 \& 2) (1995) 15-26.

[5] Barranguet C., Alliot E., Plante-Cuny M.-R., Benthic microphytic activity at two Mediterranean shellfish cultivation sites with reference to benthic fluxes, Oceanol. Acta 17 (2) (1994) 211-221.

[6] Baudinet D., Alliot E., Berland B., Grenz C., Plante-Cuny, Plante R., Salen-Picard C., Incidence of mussel culture on biogeochemical fluxes at the sediment-water interface, HydrobioJogia, 207 (1990) 187-196. 
[7] Charpy-Roubaud C.J., Production primaire des fonds meubles du lagon de Tikehau (atoll des Tuamotu, Polynésie Française), Occanol. Acta 11 (3) (1988) 241--248.

[8] Clavier J., Boucher G., Garrigue C., Benthic respiratory and photosynthetic quotients in a tropical Iagoon, C.R. Acad. Sci. Paris 317 (1994) 937--942.

[9] Davis M.W., McIntire Effects of physical gradients on the production dynamics of sediment-associated algae. Mar. Ecol. Prog. Ser. 13 (1983) 103-114.

[10] Deslous-Paoli J-M., Mazouni N., Souchu P., Pichot P., Juge C., Oyster farming impact on the environment of a Mediterranean lagoon (Thau), (Preliminary results of the Oxythau programme), in: Richard F.B., Spinger-Verlag Berlin Heidelberg. 1993, pp. 519-521.

[11] Gerbal M., Analyse spatio-temporelle des peuplements phytobenthiques de substrat meuble de l'étang de Thau (Hérault, France), Thèse Ecol., Univ. Aix-Marseille II 94 (1994) 241 p.

[12] Gerbal M., Verlaque M., Macrophytobenthos de substrat meuble de l'étang de Thau (France, Méditerranée) et facteurs environnementaux associés, Oceanol. Acta 18 (5) (1995) 557-571.

[13] Grenz C.. Plante-Cuny M.-R., Plante R., Alliot E., Baudinet D., Berland B.. Measurement of benthic nutrient fluxes in Mediterranean shellfish farms: a methodological approach, Oceanot. Acta 14 (2) (1991) 195-201.

[14] Grenz C., Alliot E., Baudinet D., Helis L., Massé H., Influence des opérations de dévasage sur les flux de nutriments à l'interface eau-sédiment (Bassin de Thau-France), Vie Milieu 42 (2) (1992) 157-164.

[15] Hargrave B.T., Prouse N.I., Philips G.A., Neame P.A., Primary production and respiration in pelagic and benthic communities at two intertidal sites in the upper bay of Fundy, Can. J. Fish. Aquat. Sci., Suppl. 1, 40 (1983) 229-243.

[16] Hargrave B.T., Duplisea D.E., Pfeiffer E., Wildish D.J., Seasonal changes in benthic fluxes of dissolved oxygen and ammonium associated with marine cultured Atlantic salmon, Mar. Ecol. Prog. Ser. 96 (1993) 249-257.

117] Mazouni N., Influence des élevages ostréicoles sur le fonctionnement d'un écosystème lagunaire méditerranéen. Etude in situ de l'influence des filtreurs (coquillages et épibiontes) sur les flux de matières particulaire et dissoute, Thèse Océanologie. Univ. Aix-Marseille II (1995) 168 p.

[18] Mazouni N., Gaertner J.-C., Deslous-Paoli J.-M., Landrein S. Geringer d'Oedenberg M., Nutrient and oxygen exchanges at the water-sediment interface in a shellfish farming lagoon (Thau. France), J. Exp. Mar. Biol. Ecol. 203 (2) (1996) 92113.

[19] Menesguen A., Présentation du phénomène d'eutrophisation littorale, in: Guillaud et Romana (Eds.), Actes du colloque national Mer et Rejets urbains, Ifremer, 1 I (1991) 35-52.
[20] Millet B., Fonctionnement hydrodynamique du bassin de Thau, Validation écologique d'un modèle numérique de circulation (programme Ecothau), Oceanol. Acta 12 (1) (1989) 3746.

[21] Murray L., Wetzel R.L., Oxygen production and consumption associated with the major autotrophic components in two temperate seagrass communities, Mar. Ecol. Prog. Ser. 38 (1987) 231-239.

[22] Nowicki B.L., Nixon S.W., Benthic community metabolism in a coastal lagoon ecosystem, Mar. Ecol. Prog. Ser. 22 (1985) $21-30$.

[23] Picot B., Péna G., Casellas C., Bondon D., Bontoux J., Interpretation of the seasonal variations of nutrients in a Mediterranean lagoon : étang de Thau. Hydrobiologia 207 (1990) 105114.

[24] Plante R., Plante-Cuny M.-R.., Reys J.-P., Photosynthetic pigments of sandy sediments on the north Mediterranean coast: their spatial distribution and its effects on sampling strategies. Mar. Ecol. Prog. Ser. 34 (1986) 133-141.

[25] Plante R., Alcolado P.M., Martinez-Iglesias J.C., Iharzabal D. Redox potential in water and sediments of the Gulf of Batabano, Cuba, Estuar. Coast. Shelf Sci. 28 (1989) 173-184.

[26] Plante-Cuny M.-R., Bodoy A., Biomasse et production primaire du phytoplancton et du microphytobenthos de deux biotopes sableux (Golfe de Fos, France), Oceanol. Acta 10 (2) (1987) $223-237$.

[27] Plante-Cuny M.-R., Barranguet C., Bonin D., Grenz C., Does chlorophyllide $a$ reduce reliability of chlorophyll a measurements in marine Coastal Sediments? Aquatic Sciences 55 (1) (1993) 19-30

[28] Rizzo W.M., Lackey G.J., Christian R.R., Significance of euphotic. subtidal sediments to oxygen and nutrient cycling in a temperate estuary, Mar. Ecol. Prog. Ser. 86 (1992) 51-61.

[29] Souchu P., Gase A., Cahet G., Vaquer A., Collos Y., DeslousPaoli J.M., Biogeochemical composition of Mediterranean waters outside Thau lagoon, Estuar. Coast. Shelf Sci. 44 (1997) 275-284.

[30] Souchu P., Gasc A., Collos Y., Vaquer A., Tournier H., Bibent B., Deslous-Paoli J.M., Biogeochemical aspects of bottom anoxia in a Mediterranean lagoon (Thau, France), Mar. Ecol. Prog. Ser. 164 (1998) 135-146.

[31] Sundbäck C., Jönsson B., Nilsson P., Lindstrom I., Impact of accumulating drifting macroalgae on a shallow-water sediment system: an experimental study, Mar. Ecol. Prog. Ser. 58 (1990) 261-274.

132] Tournier H., Deslous-Paoli J.-M., Variations spatio-temporelles estivale de l'oxygène dans les secteurs conchylicoles de l'étang de Thau, J. Rech. Océanogr. 183 (4) (1993) 71-73. 